\title{
INCREASING THE EFFICIENCY OF GRINDING PLANTS BY THE USE OF ACOUSTIC MONITORING
}

\author{
Institute of Technical Mechanics \\ of the National Academy of Sciences of Ukraine and the State Space Agency of Ukraine \\ 15 Leshko-Popel St., 49005,Dnipro, Ukraine; e-mail: np-2006@ukr.net
}

The high energy intensity of the bulk material grinding process explains the topicality of the problem of increasing the process efficiency in jet grinding plants. The aim of this paper is to analyze the results of investigations into the development of new approaches to the optimization of the dry fine grinding process and grinding product quality control.

Grinding product particle size distribution formation regularities and mechanism such that the required particle size is achieved with minimal energy consumption were established. A critical level of fine grinding energy intensity was found out. A scientific approach to reducing the specific power consumption in closed cycles of fine grinding was developed based on a balance and a simulation model.

A method was developed for jet grinding study based on acoustic monitoring of the grinding plant working areas. The process parameters were related to the acoustic ones, and the regularities of acoustic radiation from a jet grinding plant were determined. The use of acoustic monitoring in the determination of the particle size of bulk materials of various properties was justified. Experimental plants were developed for the in-flow analysis of the material particle size distribution. The dependence of the characteristic frequency dispersion on the particle mass and the fraction size in the mixture was established, which allows the contactless determination and prediction of the material particle size distribution in a gas flow. A grinding product quality control technique was developed and tested in industrial conditions.

Several lines of jet grinding optimization and a power consumption evaluation and prediction method were developed. The jet grinding regime visualization and identification system developed on the basis of information technologies and acoustic monitoring results allows one to choose the optimum parameters of the jet grinding process with a minimum of starting experimental data. There is a need to continue the development of an automated system that would control the jet grinding process based on the analysis of its acoustic signals.

Keywords acoustic monitoring, grain-size composition, quality control, jet grinding.

1. Pryadko N. S. Development of the Theory of Mineral Product Fine Grinding (in Russian): D. Sc. thesis synopsis: 05.15.08, National Mining University. - Dnipropetrovsk, 2015. 36 pp.

2. Pryadko N. Application of information technology for decrease of fine grinding power consumption. Power Engineering and Information Technologies in Technical Objects Control, Annual publication. Leiden, The Netherland: CRC Press/Balkema. 2016. Pp. 67-73.

3. Pivnyak G. G., Pilov P. I., Pryadko N. S. Decrease of power consumption in fine grinding of minerals. Mine Planning and Equipment Selection C Drebenstedt and R. Singhal (Eds). Springer International Publishing Switserland. 2014. Pp. 1069-1079. DOI: 10.1007/978-3-319-02678-7_104.

4. Pilov P. I., Pryadko N. S. Simulation of ore grinding closed loops based on control size grade balance (in Russian). Metallurgicheskaya i Gornorudnaya Promyshlenost. 2013. No. 6. Pp. 75-80.

5. Pilov P. I., Pryadko N. S., Ternova K. V. On the grinding kinetics of individual fractions in a mixture (in Russian). Zbahachennia Korysnykh Kopalyn. 2014. No. 57 (98). Pp. 101-106.

6. Saksonov G. M., Pryadko N. S., Ternova K. V. Imitating model of the mineral grinding closed cycle (in Russian). System Technologies. 2014. No. 3 (92). Pp. 19-25.

7. Saksonov G. M., Pryadko N. S., Ternova K. V. Simulation model of material fine grinding kinetics (in Russian). Vestnik NTU KhPI. 2014. No. 53 (1095). Pp. 89-97.

8. Pryadko N. S. Acoustic Study of Jet Grinding (in Russian). LAP LAMBERT Academic Publishing.OmniScriptum GmbH\&Co.Kg. Saarbrucken Germany. 2013. 172 pp.

9. Gorobets L. Zh., Pryadko N. S., Bovenko V. N. Jet grinding process acoustic study method (in Russian). Obogashchenie Rud. 2013. No. 3. Pp. 18-24.

10. Pryadko N. S. Information technologies for material fine grinding optimization (in Russian). System Technologies for Modeling of Complex Processes. 2016. Pp. 427-462.

11. Pryadko N. Optimization of fine grinding on the acoustic monitoring basis. Energy Efficiency Improvement of Geotechnical Systems. Taylor \& Francis Group, London. 2015. Pp. 99-108.

12. Method for bulk material grain-size composition determination in the process of grinding (in Ukrainian). Patent for Invention No. 114442 Ukraine, IPC $02 \quad 25 / 00,02 \quad 19 / 06$, G 01 N 29/00 / Pilov P. I., Horobets L. Zh., Pryadko N. S., Ternova K. V.; applicant and patentee Institute of Technical Mechanics of the National Academy of Sciences of Ukraine and the National Space Agency of Ukraine. No. a 2015 07099, July 16, .2015. published June 12, 2017. Bulletin No. 11. 6 pp. 
13. Ternova $K . V$. Bulk material in-flow grinding and transportation signal frequency analysis (in Russian). Zbahachenia Korysnykh Kopalyn. 2016. No. 63 (104). Pp. 59-65.

14. Pryadko N. S., Ternova K. V. Establishing the possibility of assessing the bulk material fractional composition from the frequency characteristics of acoustic signals in the flow (in Russian). Zbahachennia Korysnykh Kopalyn. 2017. No. 67 (108). Pp. $161-168$.

15. Pryadko N. S., Ternova $K$. V. Experimental study of acoustic signal characteristics in material transportation in Granulometer plants (in Russian). Zbahachennia Korysnykh Kopalyn. 2016. No. 64 (105). Pp. 111-118.

16. Ternovaya Ye. $V$. Development of model of plant for measuring dispersivity of material in energy-carrier flow based on regression analysis (in Russian). Teh. Meh. 2017. No. 1. Pp. 100-106.

17. Pryadko N. S., Ternova K. V. Acoustic monitoring based prediction of the ground product grain-size composition in magnetic quartzite dressing (in Russian). Zbahachenia Korysnykh Kopalyn. 2017. No. 68 (109). Pp. 32 36.

18. Pryadko N. S., Ternovaya Ye. V. Integral-differential equation of fine grinding kinetics (in Russian). Teh. Meh. 2016. No. 4. Pp. 104-112.

19. Sukhomlyn R. O., Mikhalyov O. I., Pryadko N. S., Ternona K. V. Study of the possibility to use the SSA decomposition in material grain-size composition assessment (in Ukrainian). Visnyk KhNTU. 2017. V. 1. No. 3 (62). Pp. 228-232.

20. Pryadko N. S., Kovalenko N. D., Strelnikov G. A. Development of theory and technology of fine grinding (in Russian). Teh. Meh. 2015. No. 4. Pp. 72-84.

21. Mikhalyov A., Pryadko N., Suhomlin R., Kotyra A. Application of wavelet transform in analysis of jet grinding process. Elektronika. 2013. No. 8. p. 20-22.

22. Pryadko N. S. Acoustic monitoring based simulation of the fine grinding process (in Russian). Teh. Meh. 2012. No. 3. .179-184.

23. Pryadko N. S. Improving of the jet grinding efficiency based on acoustic monitoring. International Conference «Innovative Technologies in Science and Education. European Experience»: Proceedings in 2 volumes. V. 1. 2017. Pp. 302-307.

24. Bevzenko B., Pilov P., Gorobets L., Pryadko N. Acoustic monitoring for optimization of grinding equipment. PES-15, Smart Innovation in Mining.SAIMM. Pp. 1155-1160.

25. Gorobets L. Zh., Pryadko N. S. Acoustic parameters of jet grinding optimization (in Russian). Zbirnyk Naukovykh Prats PolNTU. 2012. Issue 2 (32). Pp. 128-136.

26. Gorobets L. Zh., Pryadko N. S., Krasnoper V. P., Bakum P. A. Acoustic method for jet grinding power consumption assessment (in Russian). Zbahachennia Korysnykh Kopalyn. 2014. No. 56 (97). Pp. 94-102.

27. Muzyka L. V., Pryadko N. S. Technique for jet grinding automatic control based on object and control system models (in Russian). System Technologies. 2017. No. 2 (109). Pp. 51-58.

Received on July 12, 2018, in final form on September 27, .2018 